Ecology

\title{
Availability and characterization of cavities used by pacas (Cuniculus paca) in the Lacandon Rainforest, Chiapas, Mexico
}

\author{
Disponibilidad y caracterización de cavidades utilizadas por los tepezcuintles (Cuniculus paca) en \\ la Selva Lacandona, Chiapas, México
}

\author{
Avril Figueroa-de León ${ }^{\mathrm{a}, *}$, Eduardo J. Naranjo ${ }^{\mathrm{a}}$, Hugo Perales ${ }^{\mathrm{a}}$, Antonio Santos-Moreno ${ }^{\mathrm{b}}$, \\ Consuelo Lorenzo ${ }^{\text {a }}$ \\ ${ }^{a}$ El Colegio de la Frontera Sur, Carretera Panamericana y Periférico Sur s/n, 29290 San Cristóbal de Las Casas, Chiapas, Mexico \\ ${ }^{\mathrm{b}}$ Laboratorio de Ecología Animal, Centro Interdisciplinario de Investigación para el Desarrollo Integral Regional, Unidad Oaxaca, Instituto Politécnico Nacional, \\ Hornos No. 1003, Col. Noche Buena, 71230 Santa Cruz Xoxocotlán, Oaxaca, Mexico
}

Received 26 October 2015; accepted 20 May 2016

Available online 17 August 2016

\begin{abstract}
The studies of cavities used as refuges are necessary to develop effective management and conservation plans for native wildlife species and their habitats. There are no previous studies about the variables that influence the use of cavities by pacas (Cuniculus paca) in the Lacandon Rainforest of Chiapas, Mexico. The aims of this study were to identify distinctive characteristics of cavities used by pacas and to verify if these rodents used the cavities in proportion to their availability. We studied 3 sites with different land use where 42 cavities potentially used by pacas were detected and characterized, the presence of pacas was confirmed in 24 cavities using camera traps. The differences between cavities with and without paca presence were analyzed. In the study area, pacas used cavities underneath roots and inside fallen logs in secondary and riparian vegetation that were within $100 \mathrm{~m}$ from water bodies. Pacas are considerably tolerant to anthropogenic disturbances such as land use change, thereby easily adapting to fragmented landscapes.

All Rights Reserved (C 2016 Universidad Nacional Autónoma de México, Instituto de Biología. This is an open access item distributed under the Creative Commons CC License BY-NC-ND 4.0.
\end{abstract}

Keywords: Burrows; Habitat use; Preference; Paca; Shelter

\section{Resumen}

Los estudios sobre cavidades utilizadas como refugio son necesarios para desarrollar planes efectivos de manejo y conservación de las especies silvestres y sus hábitats. Las variables que influyen en el uso de las cavidades por parte del tepezcuintle (Cuniculus paca) en la Selva Lacandona, Chiapas, México, aún no han sido estudiadas. El objetivo de este trabajo fue identificar las características distintivas de las cavidades que son utilizadas por el tepezcuintle y verificar si las utiliza en proporción a su disponibilidad en 3 sitios con diferente uso de suelo. Se detectaron y caracterizaron 42 cavidades que potencialmente fueron utilizadas por esta especie. Con ayuda de cámaras trampa, la presencia de $C$. paca fue verificada en 24 cavidades. Se analizaron las diferencias entre las cavidades con presencia y ausencia de tepezcuintle. En el área de estudio, esta especie utiliza cavidades bajo raíces de árboles en pie y dentro de troncos tirados que se encuentran a menos de $100 \mathrm{~m}$ de distancia de cuerpos y corrientes de agua, en vegetación secundaria y ribereña. El tepezcuintle es considerablemente tolerante a alteraciones antrópicas y a los cambios de uso de suelo, adaptándose fácilmente a la fragmentación del paisaje.

Derechos Reservados @ 2016 Universidad Nacional Autónoma de México, Instituto de Biología. Este es un artículo de acceso abierto distribuido bajo los términos de la Licencia Creative Commons CC BY-NC-ND 4.0.

Palabras clave: Madrigueras; Uso del hábitat; Preferencia; Paca; Refugio

\footnotetext{
* Corresponding author.

E-mail address: mantabella@ hotmail.com (A. Figueroa-de León).

Peer Review under the responsibility of Universidad Nacional Autónoma de México.
} 


\section{Introduction}

Knowledge on the use and selection of resources by organisms provides primary information about their natural history and habitat requirements, conservation and management plans to develop effective policies (Caughley, 1994). Availability is a key governing aspect in resource selection studies. When a resource, such as a cavity, is used proportionally more than expected based on its overall availability, its use is referred to as selective and preference may be inferred. This happens when a resource is selected although it is available in similar quantities to other resources (Johnson, 1980).

Cavities offer protection from adverse natural conditions or from predation by other animals. Variations in structural composition and uses of cavities are related to the body size of animals using them (Hansell, 1993) as well as to other factors such as soil type, vegetation type (Laundre \& Reynolds, 1993), season, temperature, and rainfall (Domínguez-Castellanos, Meza, Mendoza, \& González). Natural cavities underneath roots, hollow trunks, crevices and gaps between rocks and holes created by other animals may be adapted and used by pacas (Cuniculus paca) as burrows (Aquino, Meléndez, Pezo, \& Gil, 2012; Pérez, 1992). The paca is a large rodent, solitary and nocturnal in Neotropical forests. Its typical habitat is close to water bodies with dense understories, it maintains both terrestrial and aquatic pathways to escape from predators (Pérez, 1992). This rodent is one of the most hunted species throughout the Neotropics because of its tasty meat (Aquino, Gil, \& Pezo, 2009; Naranjo, Guerra, Bodmer, \& Bolaños, 2004).

Pacas usually spend daytime hours sleeping inside cavities. Each individual normally uses several cavities, which can have 1 or more entrances that may be covered with leaf litter that allows them to be hidden from predators or hunters (Beck-King, Helversen, \& Beck-King, 1999; Bronner, 1992). Studies on the use of burrows and other habitat elements by pacas have been conducted in several sites (Beck-King et al., 1999; ContrerasDíaz, Santos-Moreno, Alfaro, \& Pérez-Lustre, 2009; Gallina, 1981; Parroquín, Gallina, \& León, 2010). However, detailed information on the characteristics and availability of cavities potentially used as burrows by pacas is scarce (Aquino et al., 2009; Parroquín et al., 2010), partly because it is a cautious nocturnal species occurring at low densities (Pérez, 1992). In addition, the underground tunnels going into and coming out from paca burrows are usually covered with litter, which makes them difficult to find and monitor. In the study of Parroquín et al. (2010) the characteristics of paca burrows habitats were compared to randomly selected sites, they found that dense vegetation cover, rocky and steep terrain and the presence of water bodies were relevant variables determining the selection of cavities to establish burrows. The purposes of this study were to identify characteristics of cavities used by pacas and assess if pacas are selective in their use of cavities as burrows in 3 sites with different land use within the Lacandon Rainforest of Chiapas, Mexico. We expected that pacas would selectively use cavities offering protection from predators, such as those located nearby water bodies and on steep slopes, and that the availability and use of cavities by pacas would differ between highly transformed sites within agricultural lands and undisturbed sites at both community reserve and Montes Azules Biosphere Reserve (MABR).

\section{Materials and methods}

The three study sites were located in the south-eastern sector of the MABR and in the surrounding localities of Playón de la Gloria and Reforma Agraria, within the Lacandon Rainforest of Chiapas, Mexico (Fig. 1). The MABR (3,312 $\left.\mathrm{km}^{2}\right)$ shelters some of the most diverse and best preserved tropical rainforests in Mexico. The ejidos (communal lands) of Playón de la Gloria $\left(17.4 \mathrm{~km}^{2}\right)$ and Reforma Agraria $\left(28.8 \mathrm{~km}^{2}\right)$ are on the edge of the Lacantun River. The main productive activities of residents are agriculture and cattle ranching, as well as fishing, hunting, logging and tourism services (INE, 2000). Two different land uses were distinguished in the ejidos. The first one ("anthropic") comprised riparian vegetation corridors and secondary vegetation fragments within a matrix of crops, grazing areas, and human settlements. The second one ("community reserve") were tracts of mature or secondary rainforest surrounded by croplands and pastures. Tourism and research occurred for short periods (e.g., 1 month) at both community reserves. A third type of "land use" (pristine tropical rainforest) was predominant within MABR. Human presence was scarce at this site (Fig. 1).

An intensive search for cavities used as burrows by pacas was carried out in April (dry season) and September (wet season) 2013 along 15 transects ( 5 per study site) which were $1 \mathrm{~km}$ long and $50 \mathrm{~m}$ wide (Fig. 1). The criterion for selecting the location of paths was based on the occurrence of signs of paca presence in addition to previous knowledge of residents and local guides about the presence of this mammal at a particular site. The classification of cavities was carried out during the first sampling month, grouping them into 3 categories depending on the type of substrate or supporting material: (1) underground burrows previously built by different animals, (2) natural cavities formed between and below the roots of standing trees, and (3) spaces formed on the inside of fallen trunks due to decomposition. This classification partially coincides with information found in previous studies, whereby it was observed that pacas use cavities located inside hollow trunks, tree roots of trees, and in soil depressions (Aquino, Bodmer, \& Gil, 2001; Oliveira \& Bonvicino, 2006; Parroquín et al., 2010).

Initial criteria for selecting the cavities to be evaluated were that they should have a minimum diameter of $10 \mathrm{~cm}$ and a minimum horizontal depth of $60 \mathrm{~cm}$. These measurements were based on reports from Aquino et al. (2012) on the minimum size of entrances and the minimum depths for paca burrows. The burrows were only considered when there was a clear indicator of its use by an animal, based on having an entrance and a clean opening without rubble and fresh footprints at the entrance or inside the burrow. Once located, the attributes of the burrows were characterized through the measurement of 10 different variables described in Table 1.

Afterwards, a camera trap was placed on a trunk or stake in front of or aside each cavity to verify the identity of species 

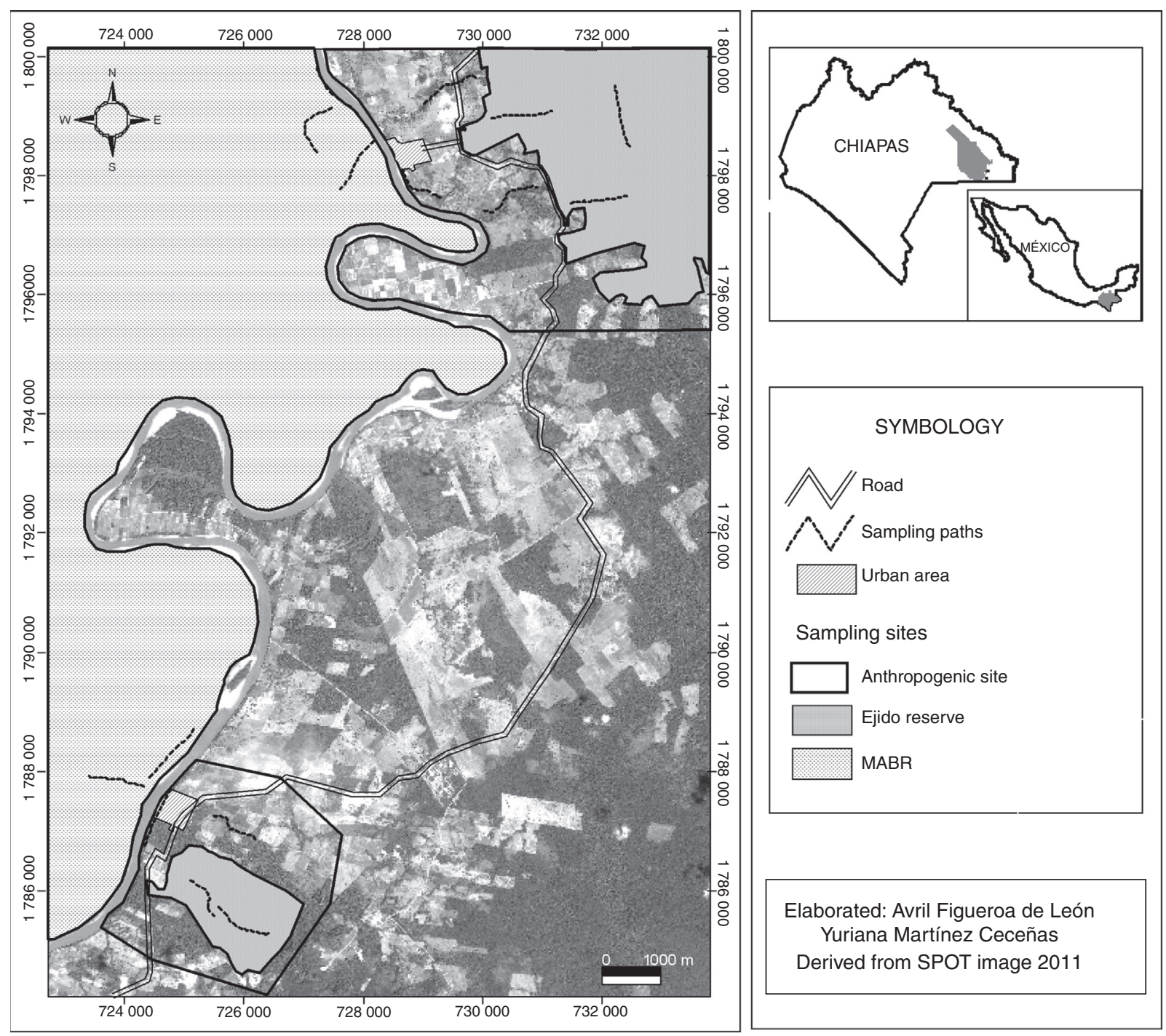

Figure 1. Map of study area in eastern Chiapas, Mexico, derived from SPOT image (2011).

present. Camera traps were left during $20-30$ consecutive days in each sampled cavity from May 2013 to July 2014 and they were programmed to be active for $24 \mathrm{~h}$ a day, taking 3 consecutive photographs when set off with an interval of $1-15 \mathrm{~s}$ between photographs or with a video for $10-30 \mathrm{~s}$.

\section{Statistical analyses}

For continuous variables that fulfilled the Shapiro-Wilk normality test (horizontal vegetation cover and cavity entrance diameter) Student's $t$ tests were applied, while Wilcoxon rank sum tests were used to compare non-normal variables (slope, rate of soil penetrability). Chi-squared tests were used to contrast between kinds of cavities and vegetation types surrounding them, distances to water bodies, soil textures, hunting pressures and sites with different land use. Generalized lineal models (GLM) were used to determine which variables (Table 1) influenced paca presence in cavities. For all cases, a logistic binomial distribution was assumed for the values associated with presence or absence of the paca in cavities, with logarithms as link functions. A base model was constructed with the variables that were statistically significant in $t$ tests, Wilcoxon rank sum test and Chi-square tests (distance to water, penetrability of the soil, cavity type, hunting pressure, and land use). We added other variables to this base model, 1 at a time, and tested for better adjustment than the base model; the process was repeated until we obtained the best adjustment for the model. The fit of each model was measured using the Akaike information criterion (AIC). All analyses were carried out with the "R" software, version 2.0-3 (Crawley, 2005; R Core Team, 2014).

Habitat use software (HABUSE; Byers, Steinhorst, \& Krausman, 1984) allowed to assess the use of cavities by pacas based on the variables measured to infer their selective use (Table 1). Habitat use studies assume: (1) the availability of resources in a particular habitat is the same for all individuals, (2) detectability is similar for individuals and species, and (3) samplings are independent (Johnson, 1980). In this study, cavities at least $100 \mathrm{~m}$ away from each other were considered independent (the radius of the species' average home range, 2.4 ha, estimated by Beck-King et al., 1999). In order to assess the availability of 
Table 1

Variables measured in potential Cuniculus paca burrows in three sites of the Lacandon Rainforest, Chiapas, Mexico, 2013.

\begin{tabular}{|c|c|c|}
\hline Name of variable & Unit & Description \\
\hline Size of entrance index (SEI) & $\mathrm{cm}$ & The index was obtained by dividing the height by the width of the burrow entrance \\
\hline $\begin{array}{l}\text { Level of soil penetrability } \\
\text { where burrow is found }\end{array}$ & $\mathrm{kg} / \mathrm{cm}^{2}$ & $\begin{array}{l}\text { A hand-held penetrometer was used. Values vary from } 0 \text { to } 4.5 \text {, with a higher value indicating } \\
\text { greater soil resistance and greater hardness }\end{array}$ \\
\hline $\begin{array}{l}\text { Slope of terrain where burrow } \\
\text { is found }\end{array}$ & $\%$ & Measured with a clinometer \\
\hline Soil texture & $\begin{array}{l}\text { Categories: } \\
1=\text { coarse texture } \\
2=\text { medium texture } \\
3=\text { fine texture }\end{array}$ & $\begin{array}{l}\text { The soil texture refers to the percentage of sand, silt and clay that are present. Soil samples } \\
\text { were collected from each burrow (approximately } 100 \mathrm{~g} \text { ) and were analyzed at the Soil } \\
\text { Laboratory of the Southern Frontier College (ECOSUR) }\end{array}$ \\
\hline Burrow type & $\begin{array}{l}\text { Categories: } \\
1=\text { underground } \\
2=\text { under roots } \\
3=\text { fallen trunks }\end{array}$ & $\begin{array}{l}\text { The type of burrow was recorded based on the structure of the cavity and its form. Type } 1 \text { : } \\
\text { underground }(>10 \mathrm{~cm}) \text {, type } 2 \text { : burrow underneath thick roots }(>10 \mathrm{~cm}) \text { of standing trees with } \\
\text { DBH }>75 \mathrm{~cm} \text {, type } 3 \text { : burrow inside fallen, decomposing trunks }\end{array}$ \\
\hline $\begin{array}{l}\text { Horizontal vegetation cover } \\
\text { on top of burrow entrance }\end{array}$ & $\%$ & $\begin{array}{l}\text { A densitometer was used to register the quantity of light that penetrates the canopy } \\
\text { (Mostacedo \& Fredericksen, 2000) }\end{array}$ \\
\hline $\begin{array}{l}\text { Type of vegetation } \\
\text { surrounding burrow }\end{array}$ & $\begin{array}{l}\text { Categories: } \\
1=\text { mature rainforest } \\
2=\text { secondary vegetation }\end{array}$ & $\begin{array}{l}\text { The vegetation types were grouped into one of the following categories: type 1: mature } \\
\text { evergreen rainforest dominated by large trees with heights over } 25 \mathrm{~m} \text {; type } 2 \text { : secondary } \\
\text { vegetation, which develops after an alternation in its original state, including abandoned } \\
\text { croplands/pastures with trees of up to } 25 \mathrm{~m} \text { high, on occasions with predominant bush cover }\end{array}$ \\
\hline $\begin{array}{l}\text { Distance of burrows to } \\
\text { permanent water bodies }\end{array}$ & $\begin{array}{l}\text { Categories: } \\
1=\leq 100 \mathrm{~m} \\
2=>100 \mathrm{~m}\end{array}$ & $\begin{array}{l}\text { This distance was measured in situ using GPS. Category } 1 \text { : all burrows located at a distance of } \\
\leq 100 \mathrm{~m} \text { from permanent water bodies, and category } 2: \text { all burrows at a greater distance. This } \\
\text { distance is based on the studies of Beck-King et al. (1999) that found that the average home } \\
\text { environment of a paca is } 2.4 \text { ha ( } 100 \mathrm{~m} \text { in radius) }\end{array}$ \\
\hline $\begin{array}{l}\text { Presence of hunting along } \\
\text { paths where burrows were } \\
\text { found }\end{array}$ & $\begin{array}{l}\text { Categories: Pressure } 1=\text { low } \\
\text { Pressure } 2=\text { high }\end{array}$ & $\begin{array}{l}\text { Hunting pressure was evaluated during the search for burrows, where the hunting of paca or } \\
\text { the destruction of their burrows was considered. A path was considered to have low hunting } \\
\text { pressure: (1) when hunting was practiced sporadically or less than } 5 \text { times a year (based on } \\
\text { information from local peoples) and to have high hunting pressure, and (2) when hunting was } \\
\text { practiced more than } 5 \text { times a year }\end{array}$ \\
\hline Sites with different land use & $\begin{array}{l}\text { Categories: } \\
1=\text { anthropogenic } \\
2=\text { community reserve } \\
3=\text { MABR }\end{array}$ & $\begin{array}{l}\text { The anthropogenic site (1) included croplands, livestock pastures and human settlements in } \\
\text { both localities. The second site, located within two communal conservation areas, was } \\
\text { surrounded by croplands and pastures, yet at the interior of the } 2 \text { areas there were mature } \\
\text { secondary forests (acahuales) and abandoned croplands, as well as mature rainforest. The } \\
\text { conservation site (3) was located in the south-eastern sector of the MABR, where mature } \\
\text { tropical rainforest was the predominant vegetation type }\end{array}$ \\
\hline
\end{tabular}

cavities, the percentage of such resources characterized by a determined variable was estimated for mature forest (category 1) and secondary vegetation (category 2). Afterwards, for these two categories the quantity of cavities used by pacas was determined and compared with their availability by Chi square tests and Bonferroni confidence limits (Byers et al., 1984).

\section{Results}

A total of 42 cavities with potential to be used by pacas were found and measured in the study area. Presence of pacas was recorded in 24 of those cavities and absence was confirmed in 18. Other vertebrate species registered through camera-trapping in 26 of the 42 cavities were the striped hog-nosed skunk (Conepatus semistriatus, 5 cavities), collared peccary (Pecari tajacu, 2 cavities), northern naked-tailed armadillo (Cabassous centralis, 4 cavities), 9-banded armadillo (Dasypus novemcinctus, 9 cavities), grey 4-eyed opossum (Philander opossum, 4 cavities), virginia opossum (Didelphis virginiana, 1 cavity), central american agouti (Dasyprocta punctata, 3 cavities), and green iguana (Iguana iguana, 1 cavity).

Cavities located in hollow logs had a DBH between 0.63 and $0.96 \mathrm{~m}$, and a length of $12-20 \mathrm{~m}$. Tree species with this kind of cavities were sonzapote (Licania platypus), mahogany (Swietenia macrophylla), amargoso (Vatairea lundelli), hormiguillo (Platymiscium dimorphandrum) and barí (Calophyllum brasiliense). The variables that had significance $(p<0.05)$ in determining the presence or absence of pacas were cavity type, distance to water, penetrability of the soil, hunting pressure, and land use (Tables 2 and 3). Therefore, pacas were present mostly in cavities underneath roots and in hollow logs within $100 \mathrm{~m}$ from water bodies, in soils with an average penetrability of $1.3 \mathrm{~kg} / \mathrm{cm}^{2}$ and with low hunting pressure. The factors mentioned above were typical of cavities found in MABR and in the anthropogenic site. In contrast, cavities without pacas were largely found in the community reserve and were mostly located underground, at distances greater than $100 \mathrm{~m}$ from water bodies, in soils with an average penetrability of $2.3 \mathrm{~kg} / \mathrm{cm}^{2}$ and heavy hunting pressure (Tables 2 and 3).

The first linear model resulting from our analyses was composed of all variables with significant differences (Tables 2 and 3). Forward and backward step-wise analyses allowed to assess the influence of each variable in subsequent models. The AIC for the initial model was 32. For the final model (AIC $=18$ ), after carrying out a step by step selection, the variables included were distance to water, texture and penetrability of the soil, cavity type, hunting pressure, and land use. 
Table 2

Comparison of the burrow variables with presence or absence of paca in the Lacandon Rainforest, Chiapas, Mexico, and significance levels $(p<0.05)$.

\begin{tabular}{|c|c|c|c|c|}
\hline Variable & Presence of paca $(n=24)$ & Absence of paca $(n=18)$ & \multicolumn{2}{|c|}{ Type of statistical test } \\
\hline Horizontal vegetation cover & 2.1 & 1.7 & -1.2 & 0.2 \\
\hline \multirow{2}{*}{ Size of entrance } & & & \multicolumn{2}{|c|}{ Wilcoxon rank sum test } \\
\hline & & & $W$ & $p<0.05$ \\
\hline Slope & 53.7 & 63.6 & 259 & 0.2 \\
\hline
\end{tabular}

Table 3

Chi-squared test calculated for burrow variables with presence and absence of pacas in the Lacandon Rainforest, Chiapas, Mexico.

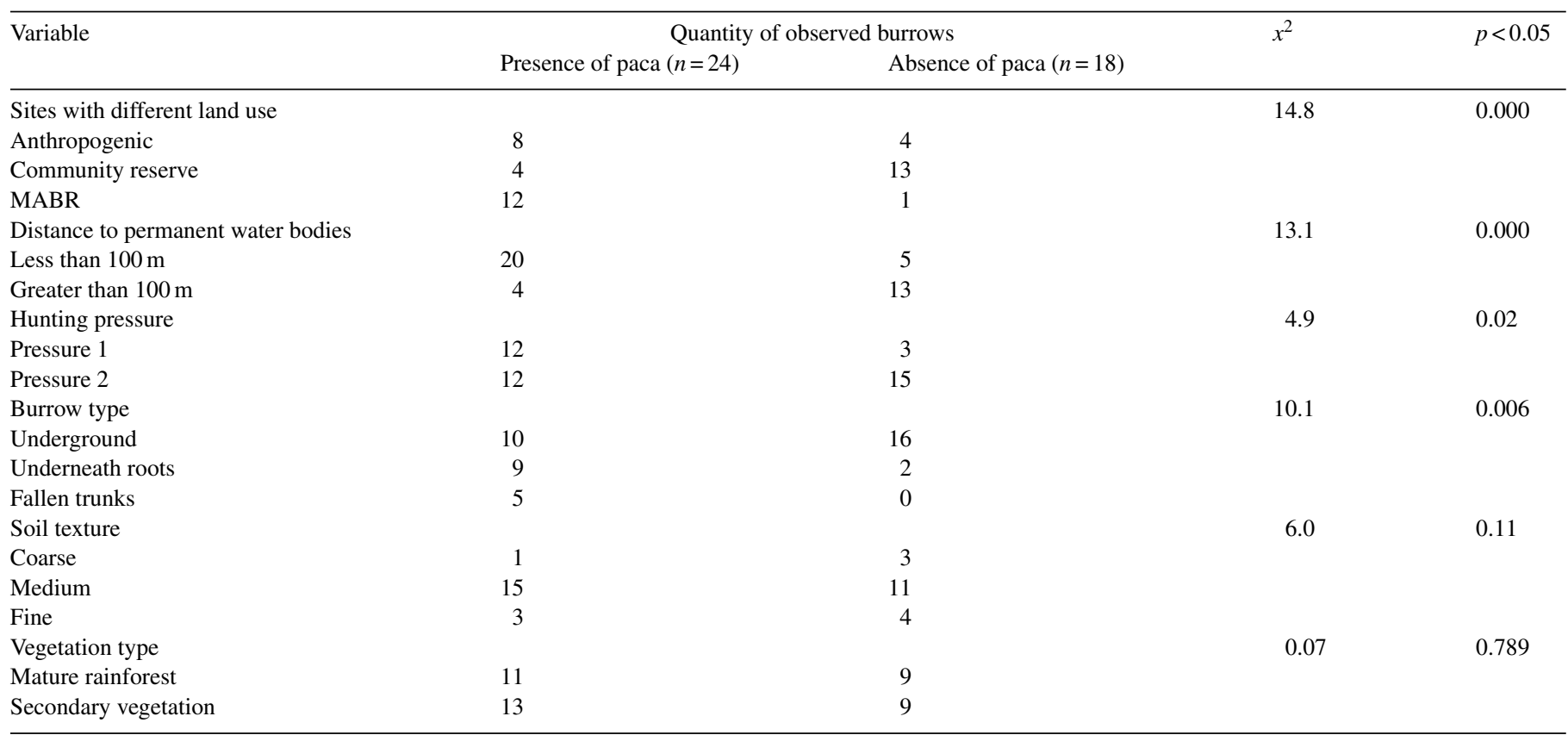

The results obtained after the analyses of cavity use suggested that entrance diameter, texture and penetrability of the soil, slope, hunting pressure, vegetation type, horizontal cover, cavity type, and distance to water did not determine more frequent use by pacas (selection of cavities) or less (avoidance) in relation to their availability. The only cavities significantly avoided $(X=6.2 ; p=0.04)$ by pacas were those located within the community reserve. Pacas used all other cavities in proportion to their availability in the study area.

\section{Discussion}

The variables found to influence the use of cavities by pacas were distance to water, texture and penetrability of the soil, cavity type, hunting pressure and land use. On the contrary, entrance size (diameter), canopy cover, vegetation type, and slope, had no effect on cavity use by this rodent. We know that distance to permanent water bodies is an important factor in the selective use of cavities by the paca. Yockteng (1982) only found paca burrows at distances shorter than $30 \mathrm{~m}$ from permanent water bodies. Aquino et al. (2009) detected $67 \%$ of paca burrows within $40 \mathrm{~m}$ from water, with emergency escape routes also oriented towards or located near water. It is relevant to mention that these rodents frequently defecate in water, which is likely to reduce the visibility of their signs and decrease predation risk. This behaviour was observed in our study area, where 25 groups of excrements were found in streams. Other variables indirectly related to distance from water bodies were soil texture and penetrability. Pacas were observed frequently in cavities underneath roots at the edges of rivers or streams, where soils were mainly soft that facilitate digging. These soils have the right texture (medium grain) to avoid landslides and keep the structure of cavities.

Cavity type was another important variable in determining the presence of the paca in cavities. This rodent used cavities, which were found underneath roots and in hollow logs. In contrast, underground cavities were avoided. This was possibly due to the fact that structures composed of thick roots and logs offer greater protection from predators and adverse weather conditions. In addition, cavities previously dug by armadillos and other mammals represent savings in the energetic input that a paca would invest in digging its own burrow (Pérez, 1992). Cavities located under thick roots offer multiple exits and entrances, 
which help to avoid predation (Aquino et al., 2012). Hunting pressure was another factor that helped to explain the presence of the paca in cavities. This mammal was present primarily in cavities found at slightly hunted sites, this coincides with previous reports in Mexico (Santos-Moreno \& Pérez-Irineo, 2013).

In the anthropogenic site, pacas used cavities in the same proportion to their availability, which also occurred in the MABR. However, in both sites the majority of cavities occupied by pacas were located underneath roots on both sides of the Lacantun River and in hollow logs within the MABR. Gallina, PérezTorres, and Guzmán-Aguirre (2012) observed that the paca is considerably tolerant to changes in land use, since this rodent was associated with secondary vegetation and croplands, which is partially concordant with our results. Some human activity, such as agriculture and associated changes in land use, can create favourable habitats for more generalist and opportunistic species (Olifiers, Gentile, \& Fiszon, 2005) due to the fact that such activities create agro-ecosystems that are spatially and temporally heterogeneous (Gentile, Andrea, Cerqueira, \& Maroja, 2000).

Pacas used underground burrows in lesser proportion to their availability at distances over $100 \mathrm{~m}$ from permanent water bodies within the community reserve. In this site, uncontrolled subsistence hunting constitutes a threat for preferred game species, with the paca being among them (Naranjo et al., 2004). Our results suggest that pacas used cavities near water $(<100 \mathrm{~m}$, the home range estimated by Beck-King et al., 1999). The hypothesis posing that the main variables influencing the use of cavities by pacas would be related to protection from predation is supported regarding distance to water, cavity type, and hunting pressure. We did not find evidence to support the hypothesis that site cavity availability and use changes with different land uses. The community reserve, despite its high availability of cavities in relation to the anthropogenic and MABR sites, was used in lower proportion to its availability, while cavities in the other 2 sites were used in proportion to their availability.

This study constitutes the first quantitative evaluation of cavity use by pacas based on their availability. The study suggests that the paca is considerably tolerant to anthropogenic disturbances such as land use change, which suggests that this species can easily adapt to fragmented landscapes as long as hunting is regulated. One of the limitations of this study is the fact that variables such as non-human predation were not considered, as it is known that this could potentially affect the use, selection and preference of cavities by pacas. Moreover, the reports for the presence or absence of this species in cavities could have had estimation errors, since only 1 camera-trap was placed for each cavity. However, since paca burrows may have more than 1 entrance, this was an additional potential drawback as reports for the absence of the species in this case could potentially be false. Finally, it is important to consider that the selection and preference of shelters are dynamic processes that vary over time, this study has the limitation that it is based on data from a single sampling of each burrow without considering temporal variations.

For an appropriate management and conservation of paca habitat, we suggest that it is important to maintain riparian vegetation with standing trees that have thick roots and abundant cavities. It is also necessary to conserve riparian corridors, living fences, and forest fragments that could serve as shelter and food sources for pacas. Likewise, we consider there is a need to regulate hunting to avoid severe population decreases that could potentially cause local extinctions of this rodent. Future studies on the use, selection and preference of cavities at multiple temporal and spatial scales would be worthwhile considering their selective, scale-dependent use by pacas.

\section{Acknowledgments}

We thank Mexico's Council of Science and Technology (Conacyt) for a Ph.D. scholarship awarded to the first author, Idea Wild provided economic support to the project. The Laboratory of Geographic Analysis and the Soil Laboratory at El Colegio de la Frontera Sur (ECOSUR) facilitated infrastructure and materials. Assistants and guides from ejidos Playón de la Gloria (Rubén Jiménez, Romeo Jiménez, and Ana Rodríguez) and Reforma Agraria (Benjamín Hernández, Sergio Chan, Celedonio Chan, Claudio Hernández, and Yazmín de la Rosa) were especially helpful during fieldwork. Special thanks to Miguel A. López, Manuel Anzueto, David Álvarez, José R. Vásquez, Esteban Pineda, Sandra Chediack, Edgar G. López, Yuriana Martínez, and Gabriela Martínez for their support in different ways.

\section{References}

Aquino, R., Bodmer, R. E., \& Gil, J. G. (2001). Mamíferos de la cuenca del río Samiria: ecología poblacional y sustentabilidad de la caza. Lima, Peru: Wildlife Conservation Society, and Programa Samiria.

Aquino, R., Gil, D., \& Pezo, E. (2009). Aspectos ecológicos y sostenibilidad de la caza del majás (Cuniculus paca) en la cuenca del río Itaya, Amazonía peruana. Revista Peruana de Biología, 16, 67-72.

Aquino, R., Meléndez, G., Pezo, E., \& Gil, D. (2012). Tipos y formas de ambientes de dormir de majás (Cuniculus paca) en la cuenca alta del río Itaya. Revista Peruana de Biología, 19, 27-34.

Beck-King, H., Helversen, O., \& Beck-King, R. (1999). Home range, population density, and food resources of Agouti paca (Rodentia: Agoutidae) in Costa Rica: a study using alternative methods. Biotropica, 31, 675-685.

Bronner, G. N. (1992). Burrow system characteristics of seven small mammal species (Mammalia: Insectivora: Rodentia: Carnivora). Koedoe, 35, 125-128. http://dx.doi.org/10.4102/koedoe.v35i1.396

Byers, C. R., Steinhorst, R. K., \& Krausman, P. R. (1984). Clarification of a technique for analysis of utilization-availability data. Journal of Wildlife Management, 48, 1050-1053.

Caughley, G. (1994). Directions in conservation biology. Journal of Animal Ecology, 63, 215-244. http://dx.doi.org/10.2307/5542

Contreras-Díaz, R. G., Santos-Moreno, A., Alfaro, A. M., \& Pérez-Lustre, M. (2009). Identificación individual de tepezcuincle (Cuniculus paca) mediante el uso de huellas. Revista Mexicana de Mastozoología (Nueva Época), 13, 34-45.

Crawley, M. J. (2005). Statistics: an introduction using R. London: Wiley.

Domínguez-Castellanos, Y., Meza, B. H., Mendoza, A., \& González, G. C. (2009). Madrigueras de Liomys pictus en dos selvas tropicales del Pacífico mexicano. Revista Mexicana de Mastozoología (Nueva Época), 13, 63-81.

Gallina, S. (1981). Contribución al conocimiento de los hábitos alimenticios del tepezcuintle (Agouti paca Lin.) en Lancaja-Chansayab, Chiapas. In P. ReyesCastillo (Ed.), Estudios ecológicos en el trópico mexicano (pp. 55-67). México, D.F: Instituto de Ecología de México. 
Gallina, S., Pérez-Torres, J., \& Guzmán-Aguirre, C. C. (2012). Use of the paca, Cuniculus paca (Rodentia: Agoutidae) in the Sierra de Tabasco State Park, Mexico. Revista de Biología Tropical, 60, 1345-1355.

Gentile, R., Andrea, P. S., Cerqueira, R., \& Maroja, L. S. (2000). Population dynamics and reproduction of marsupials and rodents in a Brazilian rural area: a five-year study. Studies on Neotropical Fauna and Environment, 9 , $1-9$.

Hansell, M. (1993). The ecological impact of animal nests and burrows. Functional Ecology, 7, 5-12. http://dx.doi.org/10.2307/2389861

INE (Instituto Nacional de Ecología). (2000). Programa de manejo Reserva de la Biosfera Montes Azules. Instituto Nacional de Ecología y Secretaría del medio ambiente y recursos naturales. Mexico, D.F.: Instituto Nacional de Ecología.

Johnson, D. H. (1980). The comparison of usage and availability measurements for evaluating resource preference. Ecology, 61, 65-71. http://dx.doi.org/10.2307/1937156

Laundre, J. W., \& Reynolds, T. D. (1993). Effects of soil structure on burrow characteristics of five small mammal species. Great Basin Naturalist, 53, 358-366.

Mostacedo, B., \& Fredericksen, T. S. (2000). Manual de métodos básicos de тиеstreo y análisis en ecología vegetal. Proyecto de Manejo Forestal Sostenible (BOLFOR). Santa Cruz, Bolivia: El País.

Naranjo, E. J., Guerra, M. M., Bodmer, R. E., \& Bolaños, J. E. (2004). Subsistence hunting by three ethnic groups of the Lacandon Forest, Mexico. Journal of Ethnobiology, 24, 233-253.
Olifiers, N., Gentile, R., \& Fiszon, J. T. (2005). Relation between small-mammal species composition and anthropic variables in the Brazilian Atlantic Forest. Brazilian Journal of Biology, 65, 495-501.

Oliveira, J., \& Bonvicino, C. (2006). Orden Rodentia. In N. Reis, A. Peracchi, P. Wagner, \& P. Isaac (Eds.), Mamíferos do Brasil (pp. 382-384). Londrina, Brasil: Universidad Estatal de Londrina.

Parroquín, J., Gallina, S., \& León, G. A. (2010). El tepezcuintle: estrategias para su aprovechamiento con base en la evaluación de su población y hábitat en el ejido Loma de Oro, Uxpanapa, Veracruz, México. In M. Guerra, S. Calmé, S. Gallina, \& E. Naranjo (Eds.), Uso y manejo de fauna silvestre en el norte de Mesoamérica (pp. 137-160). Veracruz: Secretaría de Educación, Gobierno del Estado de Veracruz, México.

Pérez, E. M. (1992). Agouti paca. Mammalian Species, 404, 1-7.

R Core Team. (2014). R: A language and environment for statistical computing. Vienna, Austria: Foundation for Statistical Computing.

Santos-Moreno, A., \& Pérez-Irineo, G. (2013). Abundancia de tepezcuintle (Cuniculus paca) y relación de su presencia con la de competidores y depredadores en una selva tropical. Therya, 4, 89-98. http://dx.doi.org/ 10.12933/therya-13-97

Yockteng, C. (1982). Observaciones ecológicas y ensayos en zoocriadero del "majás" (Agouti sp.). In S. Moller-Hergt (Ed.), Investigación y utilización de la fauna silvestre del bosque húmedo tropical, Libro III (pp. 121-154). Loreto, Perú: Comité Nacional de Programa el Hombre y La Biosfera: Proyecto UNESCO-PNUDA. 